\title{
Drivers and Drawbacks of an External Auditing Career
}

\author{
P.J. Baldacchino ${ }^{1}$, N. Tabone ${ }^{2}$, L.G. Micallef ${ }^{3}$, S. Grima ${ }^{4}$
}

\begin{abstract}
:
With this study the authors shed light on Maltese auditors' perceptions about a professional career in auditing. They examine the motivational factors that steer individuals towards a career in auditing. In addition, an analysis of the drawbacks encountered in the auditing profession from the perspective of the Maltese auditors is also carried out.
\end{abstract}

An explanatory sequential mixed method design was employed. A questionnaire was first distributed to audit practitioners working within Maltese audit firms, and 205 responses were received. This was followed by ten semi-structured interviews with auditors.

Findings highlight job security as the most significant career driver and that if Maltese auditors had to look for another job, the majority would not opt for an audit-related post but would instead move towards other accountancy-related jobs.

Moreover, it was concluded that factors such as heavy workload, stress and problems with managing work-life balance are associated with the auditing profession, especially by respondents working within Big Four audit firms in Malta.

Keywords: Auditing career, external auditing, accountancy profession, career drivers, Malta

JEL Classification: G0, M3.

\footnotetext{
${ }^{1}$ University of Malta, Head Accounts Department, Faculty of Economics, Management and Accountancy, corresponding author, peter.j.baldacchino@um.edu.mt

${ }^{2}$ University of Malta, Department of Accountancy, Faculty of Economics, Management and Accountancy,norbert.tabone@um.edu.mt

${ }^{3}$ University of Malta, Department of Accountancy, Faculty of Economics, Management and Accountancy, laragail22@ gmail.com

${ }^{4}$ University of Malta, Head Insurance Department, Faculty of Economics, Management and Accountancy, corresponding author, simon.grima@um.edu.mt
} 


\section{Introduction}

A career is "the unfolding sequence of any person's work experience over time" (Arthur and Rousseau, 1996), whilst a job is "a paid position of regular employment" (Oxford dictionaries, 2017). Yunker (2002) depicts how the connotation of a "career" differs from that of a "job". The term "job" simply refers to work which is solely done in order to make money. By simply having a job, the opportunities for advancement are restricted, and this both in terms of career position and in salary. A job has little influence on one's future work life.

On the other hand, the term "career" is about pursuing an ambitious future. The connotation of "career" focuses on lifelong goals of progressing towards positions of status and interest (Yunker, 2002). Technology advancement and knowledge expansion are evolving so rapidly that there is no such thing as a lifetime career, guaranteed in one work place. A career has become the experience of creating one's life vision (Poulsen, 2006).

Accounting is defined as: "The quantification of economic events in money terms in order to collect, record, evaluate and communicate the results of past events and to aid in decision-making" (Fernandez, 1982).

Accounting is often described as the "language of business" (Kidane, 2012). Some even argue that if accounting did not exist, the business development would have been inhibited (Ghanbari and Vaseli, 2015). Accounting does not only expose information about past events, but it also assists in projecting future estimates, thus serving as a decision-making tool (Kidane, 2012). Luca Pacioli, known as the "father of accounting", was the first contributor for the accountancy profession (Ovunda, 2015). Back in 1494, Pacioli introduced the concept of bookkeeping, where he recommended the "Venetian" method above all others. This set the tone for the importance of diminishing fraudulent actions and for presenting credible financial information to equity owners. Subsequently, Generally Accepted Accounting Principles (GAAP) were developed. It was only until afterwards that auditing first made its appearance (Ovunda, 2015).

The accountancy profession in Malta has continuously experienced a good repute, and this has led to the users' respect for the profession (Borg, 2009). Moreover, throughout the years, the profession has gone through significant changes and various accounting paths have been developed. Davis (2009) depicts four main fields of accounting being consulting, management accounting, tax and auditing. Auditing is divided into two main branches: internal and external auditing. The training, education and skills range considerably, depending on one's choice of field.

A profession is defined as a "calling requiring specialized knowledge and often long and intensive academic preparation" (Merriam-Webster Dictionary, 2017). Interestingly, paragraph 1.4 of the Maltese Accountancy Profession Act (APA) 
(Code of Ethics for Warrant Holders) Directive 2 (2016) specifies three characteristics that make up a profession:

i. primarily, the term "profession" entails proficiency in an academic skill, attained through training and qualifications.

ii. adherence by its members to a common code of values and conduct established by its administrating body, and objectivity is identified as another attribute that constitutes a profession.

iii. an acknowledgment of a "duty to society as a whole".

The APA (1979, Chap. 281) mandates that warrant holders should possess all the characteristics of a profession. Article 3(2) of the APA (1979, Chap. 281) states that a warrant to work in the profession of accountancy will only be issued if the person has the authority under law to be part of the profession, is of a decent repute and has attained the necessary qualifications. Moreover, a minimum of three years practising accounting within the industry should be accomplished. Out of these three years, one year of accounting experience shall be attained subsequent to attaining the academic qualification. Article 4(2) of the APA (1979, Chap. 281), recognises that a CPA may in addition earn a practising certificate in other fields of the accountancy profession, including auditing. Accordingly, a Practising Certificate in Auditing (PCA) may be issued.

International Standard on Auditing (ISA) 200 mandates that external audit is an assurance engagement which is carried out by a qualified auditor to give an independent opinion on whether the financial statements are prepared in accordance with an applicable financial reporting framework (International Auditing and Assurance Standards Board (IAASB), 2009a, para. 3). According to Article 179 of Maltese Companies Act (1995, Chap. 386), the opinion shall be concluded in accordance with the generally accepted auditing standards.

The audit profession has one crucial responsibility, that of acting in the best interest of the public (Baldacchino et al., 2017). This is achieved by ensuring that the users of the financial statements are provided with accurate information, which portrays the realistic financial position of the company. Thus, auditors shall carry on their duties and responsibilities with integrity and objectivity (Ardelean, 2013).

Auditing incorporates a high element of communication whilst continuously being professionally sceptical with regards to what other people are saying (Langworth, n.d.). A career in auditing does not only entail scrutinising over financial material, but also getting “under the skin of a company's culture, whilst remaining aware of the bigger picture" (Langworth, n.d.).

\section{Literature Review}


The auditing profession experiences high turnover rates amongst junior auditors (Chia et al., 2008). Chia (2003) suggested that a reason for such high turnover could be related to the realisation by new joiners that a career in auditing may not have been their perfect fit. Hence, discovering what motivates individuals to join an auditing career may assist audit firms into designing schemes to retain proficient auditors within their organisation.

Motivation may be defined as "any internal process that energizes, directs, and sustains behaviour" (Reeve, 2016). On the other hand, as stated by Ryan and Deci (2000), a person with no inspiration and motive to perform something is considered as being unmotivated. The degree and type of motivation varies from one individual to another.

Ryan and Deci (2000) describe the common phenomena of intrinsic and extrinsic motivation. Intrinsic motivation is motivation that is instigated out of interest or personal enjoyment. Extrinsic motivation is when an individual is motivated to act because it results in a "separable outcome". Examples describing the latter include financial rewards, career opportunities and fear of disappointment amongst other external factors (Pew, 2007).

According to Pew (2007), the major advantage of intrinsic motivation is that since it is triggered by one's values, interests and personal aims, such motivators are frequently available and easy to access. Unlike extrinsic motivation, it does not need reliance on external factors, such as money, to be stimulated.

Motivation is a major contributor of an auditor's performance (Suryanto and Thalassinos, 2017; Averina et al., 2016). According to Kadous and Zhou (2016), intrinsic motivation affects audit quality, such that auditors possessing a high level of intrinsic motivation will perform better audit judgements and will further enrich their professional scepticism.

\section{The Determinants of an Auditing Career:}

Francis (1985) explained that a career driver is an internal instinct which conditions what one wants and needs from their career. Career drivers are stimulated from oneself and such forces motivate a person to take action. Interestingly, it is thought that career drivers are revealed, rather than being cautiously chosen. Interpreting one's choice of a particular career initiates by examining one's driving forces (Chia, 2003).

In his study, Chia (2003) focused on the most significant career drivers for auditors. The five most important career drivers, in order of importance were the following:

i. Expertise;

ii. Status;

iii. Search for meaning;

iv. Affiliation; 
v. Material rewards.

"Expertise" and "Search for Meaning" are at the heart of the audit profession. Being open for new challenges and prospering in enhancing knowledge and personal skills is the first criteria that must be satisfied to become a successful auditor. McGrath (2001) criticized the misconception that a profession in auditing may not be challenging, arguing that: "What could be more challenging than being handed three pages of numbers and figuring out whether those numbers are materially accurate - numbers that supposedly reflect the results and assets and obligations of a company that may have operations all over the country or even all over the world?" (McGrath, 2001).

"Status", being the second most ranked career driver for auditors, reflects the fact that an auditing career has a "positive reputation for the professional status of its members" (Chia, 2003). Joāo and Coetzee (2012) further corroborated that salary and benefits (i.e. compensation) was one of the main factors that gets auditors to think twice before leaving this profession.

People who scored high in "affiliation" certainly acknowledged the fact that a major part of a job in auditing entailed meeting clients and interacting with various persons (McGrath, 2001). This also indicated that junior auditors acknowledged the importance of teamwork throughout an audit process.

Furthermore, the low selection of "security" as a career driver for practitioners in Chia's findings is in sharp contrast to studies about what steers students towards the accountancy profession (Ahmed et al., 1997; Myburgh, 2005; Chia et al., 2008). In fact, highest on the list of most important factors for accounting students identified by Myburgh (2005) and Ahmed et al. (1997) were security and availability of employment. Having said that, other research studies revealed that salary and the opportunities for advancement were the main factors that were motivating students to enrol in accountancy programmes (Mustapha and Hassan, 2012). Other research studies involving practitioners, however, have concluded that once a person started practising in the profession, other factors started to crowd out financial compensation from its importance (Chia, 2003; Tandy and Moores, 1992; Demagalhaes et al., 2011).

According to Tandy and Moores (1992), the six most important criteria that accounting professionals look for in their career were the same for both males and females. However, their order of importance differed between genders. Females ranked "advancement opportunities" first, followed by "stability", "company culture", "variety of work", "meaningfulness of work" and "continuing education" respectively. Despite ranking "advancement opportunities" first, males preference was followed by "meaningfulness of work", "variety of work", "stability", "continuing education" and "company culture" respectively. 
Similarly, the findings of Demagalhaes et al. (2011) revealed that practitioners identified "opportunity for advancement" as the second most motivational factor for pursuing an accountancy career. However, most of the participants perceived "salary" as the most important criterion, in contrast to Tandy and Moores (1992), where salary was not even rated in the first top ten influential factors. "Work-life balance", "employer culture" and "employer location" were three other factors considered as most important in the study by Demagalhaes et al. (2011).

\section{Drawbacks of the Auditing Profession:}

Various international research studies have tried to discover the reasons why individuals choose not to enter a career in the accounting field (Rhode et al., 1977; Uyar et al., 2011; Harnovinsah, 2017). Many participants who preferred a career outside accountancy confessed that they perceived an accountancy career as being tedious or too number-oriented. Since an auditor acts as a problem-solver in a number of instances and must be very attentive to certain levels of detail, the auditor's work may be perceived as being very meticulous (Hanson, 2017).

Interestingly, work stress/pressure was a common mentioned factor in opting for careers outside accountancy. Michie (2002, p.67) further argued that: "situations that are likely to cause stress are those that are unpredictable or uncontrollable, uncertain, ambiguous or unfamiliar, or involving conflict, loss or performance expectations".

Yan and Xie (2016) denoted that auditors' work stress is an amalgamation of workload, time pressure, budget control, statutory risks and on-going compliance with regulations. It was further unveiled that stress tended to influence the execution of the audit procedures and ultimately adversely affected the quality and efficiency of the overall audit. Persellin et al. (2014) further enhanced this link between stress caused by audit workload and audit quality by studying the major barriers that led to lower quality audits. Not having enough staff and deadlines were the most selected factors. In addition, continuous turnover and work exhaustion were commonly selected factors in the depicted results.

The findings of Persellin et al. (2014) indicated that "personal relationships" tended to suffer most when the hours at work increase. This was followed by "personal health" and "documentation of work performed". Such argument is further supported by Rhode et al. (1977) whose results showed that the most stated circumstance for leaving the accountancy profession was because of issues with work-life balance. Interestingly, a number of auditors mentioned the introduction of work-life balance programmes in audit firms and believed that this contributed to staff satisfaction. However, senior auditors further stated that unfortunately, audit firms were only bothered about initiating work-life balance programmes in appearance, because in fact, especially when deadlines were approaching, work-life balance was off the subject (Sweeney and McGarry, 2011). 
Benavides (2014) also added that auditing had a cyclical pattern of busy seasons and, unfortunately, personal time off may be prohibited in such periods. Large audit firms tended to offer rigid promotion schemes whereby career promotions were linked to years of experience. Benavides (2014) described how this may be perceived as a drawback for the strong performers who could perhaps be promoted at an earlier stage simply based on their outstanding performances.

In addition, Yan and Xie (2016) mentioned the legal risks and responsibilities that auditors face daily. Rahman (2016) observed that: "New regulations, requirements and increased legal exposure of auditors are also often criticised and blamed for harming the auditing profession's ability to attract and retain staff'.

Enron, Tyco, Worldcom, Parmalat and other corporate scandals instigated severe interferences by regulatory authorities . It is debatable whether or not the auditors should be held responsible for such corporate failures and such an assessment is outside the scope of this study. However, what is within the scope of this study are the repercussions that these corporate failures had on the auditing profession (Norman et al., 2015). In fact, auditors today must comply with an ever-increasing list of regulations and standards, which interleaves stress (Yan and Xie, 2016).

\section{The Maltese Scenario:}

Camilleri (2016) analysed the perceptions of three different generations about the accountancy profession. All generations agreed with the fact that "one has to do sacrifices in order to achieve success in this profession" (Camilleri, 2016). Finally, Camilleri (2016)'s findings showed that the work-life balance concept was deemed to be significant for people working within the accountancy profession in Malta. Having said that, the fact that finding the right balance is challenging for individuals within this profession also scored very high and this has been most evident in responses by Millennial Professional Accountants (MPAs).

Such findings were consistent with Gauci's (2015)'s findings which showed that almost $50 \%$ of the participants thought that maintaining the right balance between work and life became harder as one advanced through his/her career. It was further noted that because high level positions demanded more hours and responsibilities, such positions "might seem not appropriate for a working mother in a Maltese culture” (Gauci, 2015).

Interestingly, a study by Vella (2015) analysed factors that motivated students to choose accounting as their study. Whilst some students chose accounting out of personal preference, many others (circa $71 \%$ ) chose accountancy because they were aware of the large availability of jobs. Other students also mentioned job security as their primary motivator for entering accountancy courses (Vella, 2015) (Grima et. al., 2017). These findings were in line with Gauci (2015)'s results about what motivators had prompted Maltese students to enter an accountancy career. In fact, "guaranteed job as soon as they graduate" was a common mentioned motivator 
(Gauci, 2015). Furthermore, students in Vella (2015)'s study also mentioned stressful work caused by strict deadlines, long working hours and monotonous work as issues that discouraged students to become future accountants.

\section{Objectives}

Therefore, with this study the authors aim to identify and explores the major characteristics of the audit profession as perceived by Maltese external auditors, specifically to achieve the following objectives:

Objective 1: to explore the different drivers that lead professionals to choose external auditing as a career;

Objective 2: to obtain an insight of the drawbacks of the auditing profession.

\section{Methodology}

The target population related to all registered Maltese auditors listed on the Registered Auditors Register, (1,298), on the website of the Maltese Accountancy Board (MAB) (2017) as at 30 $0^{\text {th }}$ October 2017. Participants were contacted through all audit firms in Malta, by circulating hard copies of the questionnaire at a Malta Institute of Accountants (MIA) Continuing Professional Educational (CPE) event.

Data was first collected through self-administered questionnaires between $14^{\text {th }}$ November 2017 and 14 ${ }^{\text {th }}$ December 2017 (vide Appendix 1). Following this, an analysis of the findings derived from the first phase was conducted. The most striking findings were used for the development of further research questions.

Most of the questionnaire consisted of questions utilising a five-point Likert rating scale, together with other closed-ended questions consisting of dichotomous questions and multiple-choice questions. Section A of the questionnaire focused on career drivers. Primarily, some impersonal questions about the current employment were asked and this was followed by Likert type questions aimed at discovering the factors that motivated auditors to enter the profession. This was followed by Section $\mathrm{B}$ which was aimed at measuring the drawbacks of the profession. Section $\mathrm{C}$ then focused on demographical information which was deemed very useful for the subsequent statistical analysis of the data. A pilot study was first conducted and any recommendations for improvement were taken into consideration.

In total, 205 valid responses were collected. Most of the respondents were female $(58.05 \%)$. Moreover, 74 respondents $(36.10 \%)$ were of ages between 20-25 years, whilst approximately half of the participants (45.85\%) were aged between 26-35 years. The remaining participants $(18.05 \%)$ were over 35 years old. With regards to the participants' employment, 113 auditors (55.12\%) were employed with a Big Four audit firm, 84 auditors (40.98\%) with a non-Big Four audit firm and the remaining 8 auditors $(3.90 \%)$ were sole practitioners. Additionally, 32 participants 
(15.61\%) occupied a junior position, 111 participants $(54.14 \%)$ occupied the position of senior, supervisor or assistant manager and 62 participants $(30.24 \%)$ occupied the position of manager, senior manager, director or partner.

Following the analysis conducted on the responses collected from the questionnaire, an interview schedule was then prepared. Interview questions were included on the most intriguing findings of the survey. The interview schedule consisted of two main sections, in line with the research objectives of the study. The target population for the interviews consisted of managers, directors and partners specialising in audit. The reason behind such target population was mainly because such individuals, given that they were qualified auditors with substantial years of experience, would be in a better position to provide meaningful insights about the subject being studied. Three auditors from Big Four audit firms and seven auditors from other mid-tier audit firms were approached to form part of the qualitative part of this research study.

The quantitative data obtained from the questionnaires was then inputted into the statistical package to be used for quantitative analysis of the data. The IBM Statistical Package for Social Sciences (SPSS) Version 24.0. Primarily, descriptive statistics were performed in order to enhance the understanding of the questionnaire results. Subsequently, the Friedman test was used to make a comparison between the mean rating scores provided for several related statements and to identify whether these mean rating scores differed significantly.

When analysing the responses of Question 4 of the questionnaire, a Kendall-tau test was conducted to assess the internal consistency between the two related statements. Subsequently, the Kruskal-Wallis test was used in order to compare mean rating scores provided to statements between several independent groups. The Chi-Square test was also conducted to assess the association between two categorical variables.

With regard to the qualitative analysis of the study, transcripts from all the interviews were prepared. Subsequently, all responses for each question were categorised by a separate code to enhance the interpretation of such results (HewittTaylor, 2001). This process was repeated until the point where theoretical saturation was reached and hence, no further codes were required (Glaser, 1965).

\section{Results}

This Section summarizes the research findings of the study. The findings are structured and presented in line with the research objectives of the study.

Objective 1: To explore the different drivers that lead professionals to choose external auditing as a career. 
Respondents were presented with eighteen statements representing nine career drivers (Appendix 2). In order to determine whether the respondents' answers were consistent between the two related statements (corresponding to the same career driver), the Kendall-Tau test was used. All p-values scored less than 0.05, thus indicating a satisfactory internal consistency.

Security obtained the highest mean rating score $(\bar{x}=3.86)$ out of all nine career drivers that were presented in the questionnaire. This was followed by the search for meaning $(\bar{x}=3.67)$ and autonomy $(\bar{x}=3.63)$. Respondents assigned the lowest mean rating score $(\bar{x}=3.00)$ to material rewards.

Six interviewees (6/10) firmly agreed that job security was a very large positive driver in the accountancy profession. Moreover, two interviewees (2/10) pointed out that many of the students currently studying at university would be already employed by the time they finished their first year.

With regard to material rewards, interviewees (6/10) generally agreed with the quantitative results, with most of them mentioning the fact that for many years, accounting/finance related positions had always paid better salaries than audit firms did. In fact, a non-big four audit partner (1/10) stated that: "You cannot join a career in an audit firm for immediate short term gains. Unless, you tie that to a career, it does not make sense".

Additionally, another interviewee (1/10) opined that the findings of the survey could be the result of many respondents being juniors, the majority of which aim to "sponge and absorb" as much as they can during their first years. In contrast, a non-Big Four audit partner (1/10) stated that individuals do expect audit firms to meet the industry's monetary rewards, especially when individuals engage in certain family or personal commitments. In this regard, most interviewees (9/10) stated that many students tended to start off from auditing because it gave them a very wide exposure; however, after three or four years, the majority would resign and move on to a different post.

The study concluded that there were statistically significant differences $(p<0.05)$ amongst groups based on demographic factors. As illustrated in Table 1, females perceived "you want to be an expert", "you find status symbols very appealing" and "you like to have a specialist kind of status" significantly higher $(\mathrm{p}<0.05)$ than males. Furthermore, as shown in Table 2, juniors scored "you find status symbols very appealing" and "you want to look to the future and feel secure" significantly higher $(\mathrm{p}<0.05)$ than the other participants occupying higher level positions.

Table 1: Career Drivers vs. Gender

\begin{tabular}{|ll|l|l|l|}
\hline $\begin{array}{l}\text { Career } \\
\text { Gender }\end{array}$ & drivers & Mean & Std. Dev. & P-value \\
\hline$\ldots$ you strive to become rich & Male & 2.66 & 1.102 & 0.667 \\
\hline
\end{tabular}




\begin{tabular}{|c|c|c|c|c|}
\hline & Female & 2.62 & 0.991 & \\
\hline \multirow[t]{2}{*}{...you pursue a leadership role } & Male & 3.51 & 0.955 & \multirow{2}{*}{0.909} \\
\hline & Female & 3.54 & 0.900 & \\
\hline \multirow[t]{2}{*}{...the out-turn of your job has value in it } & Male & 3.71 & 0.765 & \multirow{2}{*}{0.083} \\
\hline & Female & 3.91 & 0.725 & \\
\hline \multirow[t]{2}{*}{...you want to be an expert } & Male & 3.45 & 0.890 & \multirow{2}{*}{$0.048 *$} \\
\hline & Female & 3.68 & 0.929 & \\
\hline \multirow[t]{2}{*}{...you pursue a high standard of living } & Male & 3.31 & 0.985 & \multirow{2}{*}{0.689} \\
\hline & Female & 3.39 & 0.950 & \\
\hline \multirow{2}{*}{$\begin{array}{l}\text {...you want to be able to use your creativity } \\
\text { skills in your daily tasks }\end{array}$} & Male & 3.34 & 1.013 & \multirow{2}{*}{0.936} \\
\hline & Female & 3.34 & 0.995 & \\
\hline \multirow{2}{*}{$\begin{array}{l}\text {...being in charge of other colleagues is } \\
\text { something you look up to }\end{array}$} & Male & 3.21 & 0.869 & \multirow{2}{*}{0.169} \\
\hline & Female & 3.36 & 0.899 & \\
\hline \multirow{2}{*}{$\begin{array}{l}\text {..having close relationships with other } \\
\text { colleagues is what matters the most to you }\end{array}$} & Male & 3.44 & 0.977 & \multirow{2}{*}{0.466} \\
\hline & Female & 3.57 & 0.839 & \\
\hline \multirow{2}{*}{$\begin{array}{l}\text {..you can be your own master/mistress in } \\
\text { your job }\end{array}$} & Male & 3.57 & 0.952 & \multirow{2}{*}{0.438} \\
\hline & Female & 3.67 & 0.865 & \\
\hline \multirow[t]{2}{*}{...you find status symbols very appealing } & Male & 2.86 & 0.996 & \multirow{2}{*}{$0.015^{*}$} \\
\hline & Female & 3.20 & 0.859 & \\
\hline \multirow{2}{*}{$\begin{array}{l}\text {...your first aim is to do things that you } \\
\text { personally think are significant }\end{array}$} & Male & 3.44 & 0.915 & \multirow{2}{*}{0.439} \\
\hline & Female & 3.58 & 0.719 & \\
\hline \multirow{2}{*}{$\begin{array}{l}\text {...you want to look to the future and feel } \\
\text { secure }\end{array}$} & Male & 3.85 & 0.695 & \multirow{2}{*}{0.244} \\
\hline & Female & 3.96 & 0.729 & \\
\hline \multirow[t]{2}{*}{...you like to have a "specialist" kind of status } & Male & 3.35 & 0.794 & \multirow{2}{*}{$0.014 *$} \\
\hline & Female & 3.62 & 0.725 & \\
\hline \multirow{2}{*}{$\begin{array}{l}\text {...you want a job where you make your own } \\
\text { decisions }\end{array}$} & Male & 3.66 & 0.745 & \multirow{2}{*}{0.628} \\
\hline & Female & 3.61 & 0.760 & \\
\hline \multirow{2}{*}{$\begin{array}{l}\text {...you like the fact that people think highly of } \\
\text { you }\end{array}$} & Male & 3.59 & 0.899 & \multirow{2}{*}{0.534} \\
\hline & Female & 3.52 & 0.891 & \\
\hline \multirow{2}{*}{$\begin{array}{l}\text {...you seek to create innovative things that } \\
\text { others will associate to you }\end{array}$} & Male & 3.24 & 0.969 & \\
\hline & Female & 3.38 & 0.957 & 0.427 \\
\hline ...it entails a lot of time working with other & Male & 3.53 & 0.877 & 0053 \\
\hline people & Female & 3.52 & 0.832 & 0.953 \\
\hline ...you always wanted to feel financially secure & Male & 3.72 & 0.929 & 0307 \\
\hline & Female & 3.85 & 0.840 & 0.307 \\
\hline
\end{tabular}

Table 2: Career Drivers vs. Job Position

\begin{tabular}{|c|c|c|c|c|}
\hline Career drivers & Current job position & Mean & $\begin{array}{l}\text { Std. } \\
\text { Dev. }\end{array}$ & P-value \\
\hline \multirow[t]{3}{*}{...you strive to become rich } & Junior & 2.91 & 0.995 & \multirow[t]{3}{*}{0.157} \\
\hline & Senior/Supervisor/Assistant Manager & 2.66 & 1.040 & \\
\hline & $\begin{array}{l}\text { Manager/Senior } \\
\text { Manager/Director/Partner }\end{array}$ & 2.47 & 1.036 & \\
\hline
\end{tabular}




\begin{tabular}{|c|c|c|c|c|}
\hline \multirow[t]{3}{*}{...you pursue a leadership role } & Junior & 3.63 & 0.793 & \multirow[t]{3}{*}{0.931} \\
\hline & Senior/Supervisor/Assistant Manager & 3.53 & 0.942 & \\
\hline & $\begin{array}{l}\text { Manager/Senior } \\
\text { Manager/Director/Partner }\end{array}$ & 3.47 & 0.953 & \\
\hline \multirow{3}{*}{$\begin{array}{l}\text {...the out-turn of your job has } \\
\text { value in it }\end{array}$} & Junior & 3.88 & 0.707 & \multirow[t]{3}{*}{0.909} \\
\hline & Senior/Supervisor/Assistant Manager & 3.83 & 0.749 & \\
\hline & $\begin{array}{l}\text { Manager/Senior } \\
\text { Manager/Director/Partner }\end{array}$ & 3.79 & 0.771 & \\
\hline \multirow[t]{3}{*}{...you want to be an expert } & Junior & 3.63 & 0.751 & \multirow[t]{3}{*}{0.971} \\
\hline & Senior/Supervisor/Assistant Manager & 3.54 & 0.970 & \\
\hline & $\begin{array}{l}\text { Manager/Senior } \\
\text { Manager/Director/Partner }\end{array}$ & 3.65 & 0.907 & \\
\hline \multirow{3}{*}{$\begin{array}{l}\text {...you pursue a high standard of } \\
\text { living }\end{array}$} & Junior & 3.56 & 0.759 & \multirow[t]{3}{*}{0.515} \\
\hline & Senior/Supervisor/Assistant Manager & 3.30 & 1.014 & \\
\hline & $\begin{array}{l}\text { Manager/Senior } \\
\text { Manager/Director/Partner }\end{array}$ & 3.37 & 0.962 & \\
\hline \multirow{3}{*}{$\begin{array}{l}\text {...you want to be able to use } \\
\text { your creativity skills in your } \\
\text { daily tasks }\end{array}$} & Junior & 3.31 & 0.998 & \multirow[t]{3}{*}{0.944} \\
\hline & Senior/Supervisor/Assistant Manager & 3.32 & 1.027 & \\
\hline & $\begin{array}{l}\text { Manager/Senior } \\
\text { Manager/Director/Partner }\end{array}$ & 3.40 & 0.966 & \\
\hline \multirow{3}{*}{$\begin{array}{l}\text {...being in charge of other } \\
\text { colleagues is something you look } \\
\text { up to }\end{array}$} & Junior & 2.97 & 0.822 & \multirow[t]{3}{*}{0.079} \\
\hline & Senior/Supervisor/Assistant Manager & 3.37 & 0.863 & \\
\hline & $\begin{array}{l}\text { Manager/Senior } \\
\text { Manager/Director/Partner }\end{array}$ & 3.34 & 0.940 & \\
\hline \multirow{3}{*}{$\begin{array}{l}\text {...having close relationships } \\
\text { with other colleagues is what } \\
\text { matters the most to you }\end{array}$} & Junior & 3.72 & 0.851 & \multirow[t]{3}{*}{0.272} \\
\hline & Senior/Supervisor/Assistant Manager & 3.44 & 0.941 & \\
\hline & $\begin{array}{l}\text { Manager/Senior } \\
\text { Manager/Director/Partner }\end{array}$ & 3.55 & 0.843 & \\
\hline \multirow{3}{*}{$\begin{array}{l}\text {...you can be your own } \\
\text { master/mistress in your job }\end{array}$} & Junior & 3.47 & 0.842 & \multirow[t]{3}{*}{0.050} \\
\hline & Senior/Supervisor/Assistant Manager & 3.55 & 0.902 & \\
\hline & $\begin{array}{l}\text { Manager/Senior } \\
\text { Manager/Director/Partner }\end{array}$ & 3.85 & 0.903 & \\
\hline \multirow{3}{*}{$\begin{array}{l}\text {...you find status symbols very } \\
\text { appealing }\end{array}$} & Junior & 3.22 & 0.941 & \multirow[t]{3}{*}{$0.021 *$} \\
\hline & Senior/Supervisor/Assistant Manager & 3.18 & 0.907 & \\
\hline & $\begin{array}{l}\text { Manager/Senior } \\
\text { Manager/Director/Partner }\end{array}$ & 2.76 & 0.918 & \\
\hline \multirow{3}{*}{$\begin{array}{l}\text {...your first aim is to do things } \\
\text { that you personally think are } \\
\text { significant }\end{array}$} & Junior & 3.72 & 0.851 & \multirow[t]{3}{*}{0.121} \\
\hline & Senior/Supervisor/Assistant Manager & 3.41 & 0.847 & \\
\hline & $\begin{array}{l}\text { Manager/Senior } \\
\text { Manager/Director/Partner }\end{array}$ & 3.61 & 0.686 & \\
\hline \multirow{3}{*}{$\begin{array}{l}\text {...you want to look to the future } \\
\text { and feel secure }\end{array}$} & Junior & 4.25 & 0.568 & \multirow[t]{3}{*}{$0.012 *$} \\
\hline & Senior/Supervisor/Assistant Manager & 3.86 & 0.773 & \\
\hline & $\begin{array}{l}\text { Manager/Senior } \\
\text { Manager/Director/Partner }\end{array}$ & 3.84 & 0.632 & \\
\hline \multirow{3}{*}{$\begin{array}{l}\text {...you like to have a "specialist" } \\
\text { kind of status }\end{array}$} & Junior & 3.63 & 0.793 & \multirow[t]{3}{*}{0.258} \\
\hline & Senior/Supervisor/Assistant Manager & 3.53 & 0.761 & \\
\hline & $\begin{array}{l}\text { Manager/Senior } \\
\text { Manager/Director/Partner }\end{array}$ & 3.40 & 0.757 & \\
\hline \multirow{3}{*}{$\begin{array}{l}\text {...you want a job where you } \\
\text { make your own decisions }\end{array}$} & Junior & 3.50 & 0.762 & \multirow[t]{3}{*}{0.175} \\
\hline & Senior/Supervisor/Assistant Manager & 3.60 & 0.730 & \\
\hline & $\begin{array}{l}\text { Manager/Senior } \\
\text { Manager/Director/Partner }\end{array}$ & 3.76 & 0.783 & \\
\hline
\end{tabular}




\begin{tabular}{|c|c|c|c|c|}
\hline \multirow{3}{*}{$\begin{array}{l}\text {...you like the fact that people } \\
\text { think highly of you }\end{array}$} & Junior & 3.56 & 0.840 & \multirow[t]{3}{*}{0.682} \\
\hline & Senior/Supervisor/Assistant Manager & 3.59 & 0.948 & \\
\hline & $\begin{array}{l}\text { Manager/Senior } \\
\text { Manager/Director/Partner }\end{array}$ & 3.47 & 0.824 & \\
\hline \multirow{3}{*}{$\begin{array}{l}\text {...you seek to create innovative } \\
\text { things that others will associate } \\
\text { to you }\end{array}$} & Junior & 3.50 & 0.916 & \multirow[t]{3}{*}{0.420} \\
\hline & Senior/Supervisor/Assistant Manager & 3.32 & 1.000 & \\
\hline & $\begin{array}{l}\text { Manager/Senior } \\
\text { Manager/Director/Partner }\end{array}$ & 3.24 & 0.918 & \\
\hline \multirow{3}{*}{$\begin{array}{l}\text {...it entails a lot of time working } \\
\text { with other people }\end{array}$} & Junior & 3.72 & 0.772 & \multirow[t]{3}{*}{0.275} \\
\hline & Senior/Supervisor/Assistant Manager & 3.50 & 0.873 & \\
\hline & $\begin{array}{l}\text { Manager/Senior } \\
\text { Manager/Director/Partner }\end{array}$ & 3.48 & 0.844 & \\
\hline \multirow{3}{*}{$\begin{array}{l}\text {...you always wanted to feel } \\
\text { financially secure }\end{array}$} & Junior & 4.00 & 0.880 & \multirow[t]{3}{*}{0.245} \\
\hline & Senior/Supervisor/Assistant Manager & 3.71 & 0.957 & \\
\hline & $\begin{array}{l}\text { Manager/Senior } \\
\text { Manager/Director/Partner }\end{array}$ & 3.84 & 0.706 & \\
\hline
\end{tabular}

Objective 2: To obtain an insight of the drawbacks of the profession.

When presented with a list of nine drawbacks intended to measure the major drawbacks that auditors encounter during their career, auditors assigned the highest mean rating score to an ever increasing workload $(\bar{x}=4.36)$. This was followed by "stressful and tiring work" $(\bar{x}=4.30)$ and "problems with managing work-life balance" $(\bar{x}=4.21)$. Conversely, auditors expressed strong resistance to the drawback of "limited career opportunities" $(\bar{x}=2.28)$.

Most of the interviewees (9/10) agreed with these findings and considered tight deadlines to be the major stress factor. Moreover, whilst stating that work-life balance is a frequently encountered issue, practitioners discussed several initiatives undertaken by audit firms to try and guarantee a better work-life balance environment. In this regard, interviewees (10/10) suggested a number of family friendly measures including training people to cope with the increased stress $(1 / 10)$, limiting the number of clients that the firm accepts (1/10), flexible hours $(7 / 10)$, initiation of a social committee aimed at organising a wide variety of activities for the staff (5/10), entitlement to sick leave if employees' children are sick (1/10), an additional day of leave every three years they spend working within the firm $(1 / 10)$, shifting from blocked leave to restricted leave in busy periods (1/10) and adjustments to maternity leave (1/10).

Interestingly, several differences and similarities in the perceptions about the drawbacks of the auditing profession amongst the different respondents were noted. For instance, as shown in Table 3, females scored "salaries not aligned with other industries" significantly higher $(\mathrm{p}<0.05)$ than males. In addition, Table 4 shows that managers/senior, managers/directors and partners agreed significantly more $(\mathrm{p}<0.05)$ with "the need of on-going compliance with complex laws and regulations" than their counterparts. Moreover, seniors, supervisors and assistant managers rated 
"salaries not aligned with other industries" significantly higher $(\mathrm{p}<0.05)$ than the other participants.

Table 3: Drawbacks of an Auditing Career vs. Gender

\begin{tabular}{|c|c|c|c|c|}
\hline \begin{tabular}{|llll}
$\begin{array}{l}\text { Drawbacks } \\
\text { Gender }\end{array}$ & on & an & auditing \\
\end{tabular} & profession & Mean & Std. Dev. & P-value \\
\hline \multirow{2}{*}{$\begin{array}{l}\text { The need for on-going compliance with } \\
\text { complex laws and regulations }\end{array}$} & Male & 3.74 & 1.065 & \multirow{2}{*}{0.160} \\
\hline & Female & 3.58 & 0.979 & \\
\hline \multirow[t]{2}{*}{ Stressful and tiring work } & Male & 4.26 & 0.754 & \multirow{2}{*}{0.524} \\
\hline & Female & 4.34 & 0.667 & \\
\hline \multirow[t]{2}{*}{ An ever increasing work-load } & Male & 4.34 & 0.729 & \multirow{2}{*}{0.747} \\
\hline & Female & 4.38 & 0.676 & \\
\hline \multirow[t]{2}{*}{ Problems with managing work-life balance } & Male & 4.08 & 0.923 & \multirow{2}{*}{0.091} \\
\hline & Female & 4.31 & 0.767 & \\
\hline \multirow[t]{2}{*}{ Rigid schemes for promotion } & Male & 3.03 & 0.963 & \multirow{2}{*}{0.098} \\
\hline & Female & 3.28 & 0.999 & \\
\hline \multirow[t]{2}{*}{ Salaries not aligned with other industries } & Male & 3.83 & 0.923 & \multirow[b]{2}{*}{$0.002 *$} \\
\hline & Female & 4.21 & 0.910 & \\
\hline \multirow[t]{2}{*}{ Lack of challenging assignments } & Male & 2.53 & 1.134 & \multirow{2}{*}{0.575} \\
\hline & Female & 2.64 & 1.177 & \\
\hline \multirow[t]{2}{*}{ Too number-oriented } & Male & 2.65 & 1.146 & \multirow{2}{*}{0.128} \\
\hline & Female & 2.88 & 1.059 & \\
\hline \multirow[t]{2}{*}{ Limited career opportunities } & Male & 2.29 & 1.136 & \multirow[b]{2}{*}{0.766} \\
\hline & Female & 2.27 & 0.918 & \\
\hline
\end{tabular}

Table 4: Drawbacks of the Profession vs. Job Position

\begin{tabular}{|c|c|c|c|c|}
\hline $\begin{array}{l}\text { Drawbacks in an external } \\
\text { audit career }\end{array}$ & Current job position & Mean & $\begin{array}{l}\text { Std. } \\
\text { Dev. }\end{array}$ & P-value \\
\hline \multirow{3}{*}{$\begin{array}{l}\text { The need for on-going } \\
\text { compliance with complex laws } \\
\text { and regulations }\end{array}$} & Junior & 3.41 & 0.798 & \multirow{3}{*}{$0.000 *$} \\
\hline & Senior/Supervisor/Assistant Manager & 3.41 & 0.986 & \\
\hline & $\begin{array}{l}\text { Manager/Senior } \\
\text { Manager/Director/Partner }\end{array}$ & 4.19 & 0.972 & \\
\hline \multirow[t]{3}{*}{ Stressful and tiring work } & Junior & 4.19 & 0.780 & \multirow{3}{*}{0.259} \\
\hline & Senior/Supervisor/Assistant Manager & 4.39 & 0.635 & \\
\hline & $\begin{array}{l}\text { Manager/Senior } \\
\text { Manager/Director/Partner }\end{array}$ & 4.21 & 0.771 & \\
\hline \multirow[t]{3}{*}{ An ever increasing work-load } & Junior & 4.22 & 0.706 & \multirow{3}{*}{0.277} \\
\hline & Senior/Supervisor/Assistant Manager & 4.44 & 0.598 & \\
\hline & $\begin{array}{l}\text { Manager/Senior } \\
\text { Manager/Director/Partner }\end{array}$ & 4.29 & 0.837 & \\
\hline \multirow{2}{*}{$\begin{array}{l}\text { Problems with managing } \\
\text { work-life balance }\end{array}$} & Junior & 4.31 & 0.738 & \multirow[b]{2}{*}{0.119} \\
\hline & Senior/Supervisor/Assistant Manager & 4.32 & 0.716 & \\
\hline
\end{tabular}




\begin{tabular}{|c|c|c|c|c|}
\hline & $\begin{array}{l}\text { Manager/Senior } \\
\text { Manager/Director/Partner }\end{array}$ & 3.97 & 1.040 & \\
\hline \multirow[t]{3}{*}{ Rigid schemes for promotion } & Junior & 3.31 & 0.821 & \multirow{3}{*}{0.342} \\
\hline & Senior/Supervisor/Assistant Manager & 3.20 & 1.077 & \\
\hline & $\begin{array}{l}\text { Manager/Senior } \\
\text { Manager/Director/Partner }\end{array}$ & 3.06 & 0.903 & \\
\hline \multirow{3}{*}{$\begin{array}{l}\text { Salaries not aligned with other } \\
\text { industries }\end{array}$} & Junior & 4.13 & 0.976 & \multirow{3}{*}{$0.000 *$} \\
\hline & Senior/Supervisor/Assistant Manager & 4.30 & 0.804 & \\
\hline & $\begin{array}{l}\text { Manager/Senior } \\
\text { Manager/Director/Partner }\end{array}$ & 3.56 & 0.952 & \\
\hline \multirow{3}{*}{$\begin{array}{l}\text { Lack of challenging } \\
\text { assignments }\end{array}$} & Junior & 2.59 & 1.073 & \multirow{3}{*}{0.968} \\
\hline & Senior/Supervisor/Assistant Manager & 2.59 & 1.216 & \\
\hline & $\begin{array}{l}\text { Manager/Senior } \\
\text { Manager/Director/Partner }\end{array}$ & 2.60 & 1.108 & \\
\hline \multirow[t]{3}{*}{ Too number-oriented } & Junior & 2.94 & 1.162 & \multirow{3}{*}{0.277} \\
\hline & Senior/Supervisor/Assistant Manager & 2.68 & 1.095 & \\
\hline & $\begin{array}{l}\text { Manager/Senior } \\
\text { Manager/Director/Partner }\end{array}$ & 2.89 & 1.073 & \\
\hline \multirow[t]{3}{*}{ Limited career opportunities } & Junior & 2.22 & 1.039 & \multirow{3}{*}{0.184} \\
\hline & Senior/Supervisor/Assistant Manager & 2.19 & 1.014 & \\
\hline & $\begin{array}{l}\text { Manager/Senior } \\
\text { Manager/Director/Partner }\end{array}$ & 2.47 & 0.987 & \\
\hline
\end{tabular}

The audit firm type also played an important role on the perceptions of the respondents. In fact, as illustrated in Table 5, sole practitioners had a significantly higher mean score $(\mathrm{p}<0.05)$ for "the need for on-going compliance with complex laws and regulations" and "limited career opportunities" than auditors working with a Big Four audit firm and auditors working with a non-Big Four audit firm. Moreover, a strong link emerged between those working in Big Four audit firms and their level of agreement to certain drawbacks. In this regard, auditors in Big Four audit firms scored "salaries not aligned with other industries", "problems with managing work-life balance" and "stressful and tiring work" significantly higher $(\mathrm{p}<0.05)$ than their counterparts.

In addition, sole practitioners and auditors working within a Big Four audit firm rated the drawback of "an ever increasing workload" considerably higher $(\mathrm{p}<0.05)$ than the auditors employed with a non-Big Four audit firm. 
Overall, respondents emphasised that personal health $(\bar{x}=4.10)$ tends to suffer the most when faced with heavy workloads and claimed heavy workloads $(\bar{x}=4.50)$ and strict deadlines $(\bar{x}=4.41)$ to be the main contributors of stress.

Table 5: Drawbacks of an Auditing Career vs. Audit Firm Type

\begin{tabular}{|c|c|c|c|c|}
\hline Drawbacks of an auditing profession & Audit firm type & Mean & $\begin{array}{l}\text { Std. } \\
\text { Dev. }\end{array}$ & P-value \\
\hline \multirow{3}{*}{$\begin{array}{l}\text { The need for on-going compliance with } \\
\text { complex laws and regulations }\end{array}$} & Big 4 audit firm & 3.44 & 1.035 & \multirow{3}{*}{$0.001 *$} \\
\hline & Non-big 4 audit firm & 3.86 & 0.959 & \\
\hline & Sole practitioner & 4.38 & 0.518 & \\
\hline \multirow[t]{3}{*}{ Stressful and tiring work } & Big 4 audit firm & 4.46 & 0.641 & \multirow{3}{*}{$0.001 *$} \\
\hline & Non-big 4 audit firm & 4.10 & 0.754 & \\
\hline & Sole practitioner & 4.25 & 0.463 & \\
\hline \multirow[t]{3}{*}{ An ever increasing work-load } & Big 4 audit firm & 4.50 & 0.614 & \multirow{3}{*}{$0.006^{*}$} \\
\hline & Non-big 4 audit firm & 4.17 & 0.774 & \\
\hline & Sole practitioner & 4.50 & 0.535 & \\
\hline \multirow[t]{3}{*}{ Problems with managing work-life balance } & Big 4 audit firm & 4.53 & 0.613 & \multirow{3}{*}{$0.000^{*}$} \\
\hline & Non-big 4 audit firm & 3.82 & 0.946 & \\
\hline & Sole practitioner & 3.88 & 0.641 & \\
\hline \multirow[t]{3}{*}{ Rigid schemes for promotion } & Big 4 audit firm & 3.25 & 1.073 & \multirow{3}{*}{0.465} \\
\hline & Non-big 4 audit firm & 3.07 & 0.875 & \\
\hline & Sole practitioner & 3.25 & 0.886 & \\
\hline \multirow[t]{3}{*}{ Salaries not aligned with other industries } & Big 4 audit firm & 4.36 & 0.745 & \multirow{3}{*}{$0.000 *$} \\
\hline & Non-big 4 audit firm & 3.70 & 0.991 & \\
\hline & Sole practitioner & 3.25 & 1.035 & \\
\hline \multirow[t]{3}{*}{ Lack of challenging assignments } & Big 4 audit firm & 2.50 & 1.174 & \multirow{3}{*}{0.144} \\
\hline & Non-big 4 audit firm & 2.68 & 1.153 & \\
\hline & Sole practitioner & 3.13 & 0.835 & \\
\hline \multirow[t]{3}{*}{ Too number-oriented } & Big 4 audit firm & 2.80 & 1.151 & \multirow{3}{*}{0.680} \\
\hline & Non-big 4 audit firm & 2.74 & 1.031 & \\
\hline & Sole practitioner & 3.13 & 1.126 & \\
\hline \multirow[t]{3}{*}{ Limited career opportunities } & Big 4 audit firm & 2.12 & 0.943 & \multirow{3}{*}{$0.020^{*}$} \\
\hline & Non-big 4 audit firm & 2.44 & 1.079 & \\
\hline & Sole practitioner & 2.88 & 0.835 & \\
\hline
\end{tabular}

\section{Discussion on Findings}

The first research objective aimed at identifying the motivational factors that stimulate individuals to join the auditing profession. Whilst considering job security to be the primary motivator, material rewards were perceived as being the least motivating factor. This supports the findings of various studies such as Ahmed et al. (1997), Myburgh (2005), Chia et al. (2008) who identified that the primary motivators that steer students towards accountancy were security and availability of 
employment. Similar observations about the perceived importance of job security by accounting students were also researched in Malta by Vella (2015) and Gauci (2015).

Despite this, the results contrast with Chia (2003)'s findings where junior audit practitioners scored low mean values for security. Chia (2003) justified this result by stating that "perhaps the junior auditors in the current study are new entrants to the profession and may not attach too much importance to job security". Conversely, in this study, quantitative findings showed that security was one of the career drivers which was rated significantly higher $(\mathrm{p}<0.05)$ by juniors than the other counterparts, thus conflicting with Chia (2003)'s conclusions.

Interestingly, as was the case in a study by Tandy and Moores (1992), the results provided preliminary indications that money is not a strong motivator for Maltese auditors. This contrasts with the findings of Mustapha and Hassan (2012) and Demagalhaes et al. (2011) which revealed that salary had a powerful influence on individuals that enrol in accountancy courses.

A plausible explanation to this is the difference in the respondent groups. Whilst this study and Tandy and Moores (1992) targeted audit practitioners, Mustapha and Hassan (2012) and Demagalhaes et al. (2011) targeted students pursuing an accountancy career. In this regard, interviewees hinted that at lower levels, the preliminary focus of any auditor would always be on acquiring as much knowledge as possible. Moreover, in an auditing career, one can never expect immediate shortterm gains. At least at junior and senior levels, the salaries are not comparable to those offered by industry.

In this regard, audit practitioners appeared to think that after two or three years working in an audit firm, material rewards would ultimately become the main career driver and hence, that is why many auditors would start moving away from an auditing career. This contrasts with Chia (2003), Tandy and Moores (1992) and Demagalheas et al. (2011) who believed that once a person has entered a profession, factors other than material rewards become the ultimate career drivers.

Furthermore, in their study, Tandy and Moores (1992) found that males and females ranked the importance of career drivers differently. For instance, whilst stability was scored higher by females, continuing education was scored higher by males. In this study, no significant differences were found between the mean rating scores of females and males with regards to job security and, in contrast to the foreign studies, females scored "you want to be an expert", "you like to have a specialist kind of status" and "you find status symbols very appealing" significantly higher $(\mathrm{p}<0.05)$ than males. Interestingly, if the results are compared against Maslow's hierarchy of human needs, it seems that female auditors are more inclined towards the higherlevel needs such as expertise and status. 
The results show that the auditing profession is considered a stressful one, along with the fact that auditors regularly face an ever-increasing workload and severe problems in managing their work-life balance. This result does not support the hypothesis by Hanson (2017) specifying that the major weakness in the auditing profession is that it is too number-oriented, monotonous and meticulous.

Respondents indicated that stress is likely to arise owing to the heavy workload, strict deadlines and long working hours which auditors face on a regular basis. This confirms the earlier findings by Persellin et al. (2014) and Vella (2015) that exhaustion work schedule and deadlines along with shortage in staff are common stressors. As initially discovered by Yan and Xie (2016), it was confirmed by a nonBig Four audit partner (1/10) that the continuous changes in regulations and compliance thereto can cause a lot of stress.

Interestingly, personal health and relationships with family members resulted to be the major factors that suffer the most when auditors are faced with a heavy workload. This result confirms similar assertions by Persellin et al. (2014). Moreover, in a prior Maltese study it was discovered that $49.7 \%$ of the participants find it harder to maintain a work-life balance as they progress in their career and owing to this, high level positions might seem inappropriate for working mothers in the prevailing culture (Gauci, 2015). Contrary to this, results provided no significant statistical differences between the responses of different job positions to the drawback of work-life balance. Moreover, although again there were no significant statistical differences between the responses of males and females to the drawback of work-life balance, results show that there was a higher percentage of males occupying high level positions (managers, senior managers, directors or partners) when compared to females.

Furthermore, in contrast with Sweeney and McGarry (2011)'s argument, when expressing their opinion concerning the importance of work-life balance, various practitioners acknowledged the various efforts undertaken by audit firms to achieve a better work-life balance environment. In this regard, the findings highlighted that flexible hours appeared to be the practice most resorted to by Maltese audit firms. A plausible explanation to this might be because flexibility has become key in retaining mothers in today's workforce.

Moreover, a strong link emerged between those who do not aim to remain in their current employment (in the next three years) and their level of agreement with regards to the drawbacks perceived in an auditing career. In this regard, survey responses indicated that the highest turnover rate existed amongst seniors, supervisors and assistant managers.

As brought to light from the interviews held, it is typical that after attaining the required qualifications, people start their working career in an auditing post and, when they reach a somewhat higher level in the organisational hierarchy, they move 
on to other accountancy jobs rather than sticking to audit. Furthermore, many of the survey participants $(38.9 \%)$ who stated that they would leave their current employment in the upcoming three years worked with a Big Four audit firm. This was probably due to certain drawbacks which, as highlighted in the findings, seemed to be more frequently encountered by auditors employed within the Big Four audit firms.

\section{Conclusion}

Maltese auditors consider personal fulfilment (search for meaning) and autonomy as important motivators. Despite having a steep learning curve, the opportunities to continuously acquire new knowledge and impart that knowledge to other people is what makes an auditing career fulfilling. Several drawbacks, possibly leading to high employee turnover, have been identified, which in turn might encourage audit firms to react in order to mitigate such matters. Even though various audit firms were engaging in work-life balance initiatives, during busy seasons, auditors were regularly required to work longer hours.

This study has focused exclusively on Maltese audit practitioners. However, this research may be extended to discover the perceptions of students, tax practitioners, accountants and professionals working within the advisory departments. Our study also revealed audit firms regularly face staff shortage problems. We believe that it is interesting to explain the factors that lead to such an occurrence and an analysis thereof can be made in the future.

Moreover, this study showed that practitioners working within Big Four audit firms consider the auditing profession to be more stressful and tiring than those working with non-Big Four audit firms. Hence, exploring the factors that make practitioners working within Big Four audit firms perceive auditing as being more stressful than smaller audit firms and how this affects the overall audit quality would be an intriguing area for further research.

\section{Appendix 1: Questionnaire}

This Appendix presents the questionnaire that was circulated to audit practitioners.

Section A: Career Drivers

Q1. How long you have been employed with your current audit firm?

Less than 12 months

1-5 years

6-10 years

11-15 years 


\begin{tabular}{|l|||l|l|}
\hline 16-20 years & \\
\hline Over 20 years & \\
\hline
\end{tabular}

\section{Q2. In the absence of unforeseen circumstances, I aim to remain with my current employer for the next 3 years.}

Yes

No

\section{Q3. If I had to search for another job, I would certainly:}

\section{Choose an auditing job elsewhere}

Not choose an auditing job but certainly a job within the accountancy field

\section{Other}

\section{Q4. You joined an external auditing career because...}

\begin{tabular}{|l|l|l|l|l|l}
$\begin{array}{l}\text { Please specify your level of agreement } \\
\text { to the following: }\end{array}$ & $\begin{array}{l}\text { Strongly } \\
\text { Disagre } \\
\text { e }\end{array}$ & Disagree
\end{tabular} \mid $\begin{aligned} & \text { Neutral } \\
& \text { Agree }\end{aligned}$

...you strive to become rich

...you pursue a leadership role

...the out-turn of your job has value in it

...you want to be an expert

...you pursue a high standard of living

...you want to be able to use your creativity skills in your daily tasks

...being in charge of other colleagues is something you look up to

...having close relationships with other colleagues is what matters the most to you

...you can be your own master/mistress in your job

...you find status symbols very appealing

...your first aim is to do things that you personally think are significant

...you want to look to the future and feel secure

...you like to have a 'specialist' kind of status 
...you want a job where you make your own decisions

...you like the fact that people think highly of you

...you seek to create innovative things that others will associate to you

...it entails a lot of time working with other people

...you always wanted to feel

financially secure

\section{Section B: Drawbacks of an Auditing Profession}

\begin{tabular}{|c|c|c|c|c|c|}
\hline $\begin{array}{l}\text { Please specify your level of agreement } \\
\text { to the following: }\end{array}$ & $\begin{array}{l}\text { Strongly } \\
\text { Disagre } \\
e\end{array}$ & $\begin{array}{l}\text { Disagre } \\
e\end{array}$ & Neutral & Agree & $\begin{array}{l}\text { Strongly } \\
\text { Agree }\end{array}$ \\
\hline \multicolumn{6}{|l|}{$\begin{array}{l}\text { The need for on-going compliance } \\
\text { with complex laws and regulations }\end{array}$} \\
\hline \multicolumn{6}{|l|}{ Stressful and tiring work } \\
\hline \multicolumn{6}{|l|}{ An ever increasing work-load } \\
\hline \multicolumn{6}{|l|}{$\begin{array}{l}\text { Problems with managing work-life } \\
\text { balance }\end{array}$} \\
\hline \multicolumn{6}{|l|}{ Rigid schemes for promotions } \\
\hline \multicolumn{6}{|l|}{$\begin{array}{l}\text { Salaries not aligned with other } \\
\text { industries }\end{array}$} \\
\hline \multicolumn{6}{|l|}{ Lack of challenging assignments } \\
\hline \multicolumn{6}{|l|}{ Too number-oriented } \\
\hline Limited career opportunities & & & & & \\
\hline
\end{tabular}

\section{Q6. In your opinion, when faced with heavy workload, what tends to suffer the} most?

Please specify your level of agreement to the following:

\begin{tabular}{|l|l|l|l|l|}
$\begin{array}{l}\text { Strongly } \\
\text { Disagre } \\
\text { e }\end{array}$ & Disagree & Neutral & Agree & $\begin{array}{l}\text { Strong } \\
\text { ly } \\
\text { Agree }\end{array}$ \\
\hline
\end{tabular}

Relationships with family members

Relationships with clients

Relationships with your colleagues

Personal health

Quality of work carried out 
The exercised level of professional scepticism

The amount of audit evidence gathered

The relevance and reliability of audit procedures carried out

\section{Q7. In your opinion, what triggers stress?}

\begin{tabular}{|l|l|l|l|l|l|}
\hline $\begin{array}{l}\text { Please specify your level of agreement } \\
\text { to the following: }\end{array}$ & $\begin{array}{l}\text { Strongly } \\
\text { Disagre } \\
\text { e }\end{array}$ & $\begin{array}{l}\text { Disagre } \\
\text { e }\end{array}$ & Neutral & Agree & $\begin{array}{l}\text { Strongly } \\
\text { Agree }\end{array}$ \\
\hline Lack of staff & & & & \\
\hline Strict deadlines & & & & \\
\hline Frequent staff turnover & & & & \\
\hline Long working hours & & & & \\
\hline Heavy workload & & & & \\
\hline Budget constraints & & & \\
\hline Lack of supervision from superior & & & \\
\hline
\end{tabular}

\section{Section C: Demographical Information}

This information is needed for statistical analysis. All responses are strictly confidential and anonymous. Please tick the correct box.

\begin{tabular}{|l|||}
\hline Qale \\
\hline Female \\
\hline Q9. Age Group \\
\hline 20-25 years \\
\hline $\mathbf{2 6 - 3 5}$ years \\
\hline $\mathbf{3 6 - 4 5}$ years \\
\hline $\mathbf{4 6 - 5 5}$ years \\
\hline $\mathbf{5 6 - 6 0}$ years \\
\hline Over 60 years \\
\hline Q10. Current Employment \\
\hline Big 4 Audit Firm \\
\hline Non-big 4 Audit Firm \\
\hline
\end{tabular}




\section{Sole Practitioner}

\section{Q11. Current Job Position \\ Junior}

\section{Senior}

\section{Supervisor}

\section{Assistant Manager}

\section{Manager or Senior Manager}

\section{Director/Partner}

\section{Appendix 2: Career Drivers}

This Appendix presents the eighteen statements which represent the nine career drivers.

\begin{tabular}{|c|c|}
\hline Career Driver Description & $\begin{array}{l}\text { Career } \\
\text { Drivers }\end{array}$ \\
\hline ...you want to look to the future and feel secure & \multirow{2}{*}{ Security } \\
\hline ...you always wanted to feel financially secure & \\
\hline ...the out-turn of your job has value in it & \multirow{2}{*}{$\begin{array}{l}\text { Search for } \\
\text { Meaning }\end{array}$} \\
\hline ...your first aim is to do things that you personally think are significant & \\
\hline ...you can be your own master/mistress in your job & \multirow{2}{*}{ Autonomy } \\
\hline ...you want a job where you make your own decisions & \\
\hline ...you want to be an expert & \multirow{2}{*}{ Expertise } \\
\hline ...you like to have a "specialist" kind of status & \\
\hline ...having close relationships with other colleagues is what matters the most to you & \multirow{2}{*}{ Affiliation } \\
\hline ...it entails a lot of time working with other people & \\
\hline ...you pursue a leadership role & \multirow{2}{*}{$\begin{array}{l}\text { Power/ } \\
\text { Influence }\end{array}$} \\
\hline ...being in charge of other colleagues is something you look up to & \\
\hline ...you want to be able to use your creativity skills in your daily tasks & \multirow{2}{*}{ Creativity } \\
\hline ...you seek to create innovative things that others will associate to you & \\
\hline ....you find status symbols very appealing & \multirow{2}{*}{ Status } \\
\hline ...you like the fact that people think highly of you & \\
\hline ...you strive to become rich & \multirow{2}{*}{$\begin{array}{l}\text { Material } \\
\text { Rewards }\end{array}$} \\
\hline ...you pursue a high standard of living & \\
\hline
\end{tabular}

\section{References:}

Accountancy Board. 2017. Registered Auditors Register. Government of Malta. https://secure3.gov.mt/accountancyboard/Registers/RegisteredAuditors.aspx. 
Ahmed, K., Alam, K.F. and Alam, M. 1997. An empirical study of factors affecting accounting students' career choice in New Zealand. Accounting Education, 6(4), 325-335.

Ardelean, A. 2013. Auditors' Ethics and their Impact on Public Trust. Procedia - Social and Behavioral Science, 92, 55-60.

Arthur, M.B. and Rousseau, D.M. 1996. The Boundaryless Career: A new employment principle for a new organizational era. New York, Oxford University Press.

Averina, I.O., Kolesnik, F.N., Makarova, M.L. 2016. The Integration of the Accounting System for Implementing World Class Manufacturing (WCM) Principles. European Research Studies Journal, 19(3) Part A, 53-69.

Baldacchino, J.P., Caruana, R., Grima, S., Bezzina, H.F. 2017. Selected Behavioural Factors in Client-Initiated Auditor Changes: The Client-Auditor Perspectives. European Research Studies Journal, 20(2A), 16-47.

Benavides, R. 2014. Big 4 Accounting Firms: Pros and Cons. http://big4playbook.com/accounting/big-4-pros-cons/.

Borg, A. 2009. Becoming the Accountant of Tomorrow: Trends Affecting the Next Generation of Maltese Accountants. B. Accountancy (Hons) Dissertation, Faculty of Economics, Management and Accountancy, University of Malta.

Camilleri, L. 2016. The Accountancy Profession as Perceived by Three Generations of Professional Accountants. Master in Accountancy Dissertation, Faculty of Economics, Management and Accountancy, University of Malta.

Chia, Y.M. 2003. Career drivers of junior auditors: an exploratory study. Managerial Auditing Journal, 18(2), 100-111.

Chia, Y.M., Koh, H.C. and Pragasam, J. 2008. An international study of career drivers of accounting students in Singapore, Australia and Hong Kong. Journal of Education and Work, 21(1), 41-60.

Davis, A. 2009. Pursuing a Career in Accounting? Opportunities Are Yours For the Taking. http://ezinearticles.com/?Pursuing-a-Career-in-Accounting?-Opportunities-AreYours-For-the-Taking\&id=2997826.

Demagalhaes, R., Wilde, H. and Fitzgerald, L.R. 2011. Factors Affecting Accounting Students' Employment Choices: A Comparison of Students' and Practitioners' Views. Journal of Higher Education Theory and Practice, 11(2), 32-40.

Fernandez, J. 1982. An introduction to accountancy. Hyphen, 3(2), 73-77.

Francis, D. 1985. Managing your own career, London: Fontana.

Gauci, L. 2015. The Growth of the Maltese Accountancy Profession - An Analysis. Master in Accountancy Dissertation, Faculty of Economics, Management and Accountancy, University of Malta.

Ghanbari, M. and Vaseli, S. 2015. The Role of Management Accounting in the Organization. International Research Journal of Applied and Basic Sciences, 9(11), 1912-1915.

Glaser, B.G. 1965. The Constant Comparative Method of Qualitative Analysis. Social Problems, 12(4), 436-445.

Grima, S., Seychell, S., Bezzina, F. 2017. Investigating Factors Predicting Derivative Mishandling: A Sociological Perspective. European Research Studies Journal, 20(4A), 3-17.

Hanson, G. 2017. 10 Must-Know Pros \& Cons of an Accounting Career. Available from http://www.rasmussen.edu/degrees/business/blog/must-know-pros-consaccounting-career/. 
Harnovinsah. 2017. Career Decision of Accounting Students and Its Influencing Factors: A Study of University Accounting Students in DKI Jakarta, Indonesia. International Journal of Finance and Accounting, 6(2), 59-65.

Hewitt-Taylor, J. 2001. Use of constant comparative analysis in qualitative research. Nursing Standard, 15(42), 39-42.

International Auditing and Assurance Standards Board. 2009a. International Standard on Auditing 200: Overall Objectives of the Independent Auditor and the Conduct of an Audit in Accordance with International Standards on Auditing. International Federation of Accountants, New York, USA. http://www.ifac.org/system/files/downloads/a008-2010-iaasb-handbook-isa200.pdf.

Joāo, T.F. and Coetzee, M. 2012. Job Retention Factors, Perceived Career Mobility and Organisational Commitment in the South African Financial Sector. Journal of Psychology in Africa, 22(1), 69-76.

Kadous, K. and Zhou, Y.D. 2016. How Does Intrinsic Motivation Improve Auditor Skepticism in Complex Audit Tasks? http://dx.doi.org/10.2139/ssrn.2576984.

Kidane, F. 2012. Decision-making and the role of management accounting function - A review of empirical literature", Radix International Journal of Banking, Finance and Accounting, 1(4), 1-20.

Langworth, H. (n.d.), Why you should consider becoming an auditor. [online] Available from http://thegatewayonline.com/accounting/types-of-work/kpmg-why-youshould-become-an-auditor.

McGrath, S. 2001. If I could do it over again. The CPA Journal, 71(11), p. 80.

Merriam-Webster Dictionary. 2017. Profession. https://www.merriamwebster.com/dictionary/profession.

Michie, S. 2002. Causes and Management of Stress at Work. Journal of Occupational and Environmental Medicine, 59, 67-72.

Mustapha, M. and Hassan, H.A. 2012. Accounting Students' Perception on Pursuing Professional Examination. International Journal of Education, 4(4), 1-15.

Myburgh, J.E. 2005. An empirical analysis of career choice factors that influence first-year Accounting students at the University of Pretoria: A cross-racial study. Meditari Accountancy Research, 13(2), 35-48.

Norman, L.M., Tobedza, G. and Swami, B.N. 2015. Challenges Faced by External Auditors in Botswana. International Journal of Social Sciences and Humanities, 1(2), 38-49.

Ovunda, A.S. 2015. Luca Pacioli’s Double-Entry System of Accounting: A Critique.

Research Journal of Finance and Accounting, 6(18), 132-139.

Oxford dictionaries. 2017. Job. Oxford University Press. https://en.oxforddictionaries.com/definition/jobgb0124420.

Persellin, J., Schmidt, J. and Wilkins, M.S. 2014. Auditor Perceptions of Audit Workload, Audit Quality, and the Auditing Profession. Trinity University, School of Business Faculty Research.

http://digitalcommons.trinity.edu/cgi/viewcontent.cgi?article=1040\&context=busa dmin_faculty.

Pew, S. 2007. Andragogy and Pedagogy as Foundational Theory for Student Motivation in Higher Education”, InSight: A Collection of Faculty Scholarship, 2, 14-25.

Poulsen, K.M. 2006. Implementing Successful Mentoring Programs: Career Definition vs Mentoring Approach. Industrial and Commercial Training, 38(5), 251-258. 
Rahman, M.S. 2016. The Advantages and Disadvantages of Using Qualitative and Quantitative Approaches and Methods in Language Testing and Assessment Research: A Literature Review. Journal of Education and Learning, 6(1), 102-112.

Reeve, J. 2016. A grand theory of motivation: Why not? Motivation and Emotion, 40(1), 3135 .

Rhode, J.G., Sorensen, J.E. and Lawler, E.E. 1977. Sources of Professional Staff Turnover in Public Accounting Firms Revealed by the Exit Interview. Accounting, Organizations and Society, 2(2), 165-175.

Ryan, R.M. and Deci, E.L. 2000. Intrinsic and Extrinsic Motivations: Classic Definitions and New Directions. Contemporary Educational Psychology, 25(1), 54-67.

Suryanto, T., Thalassinos, I.E. 2017. Cultural Ethics and Consequences in Whistle-Blowing among Professional Accountants: An Empirical Analysis. Journal of Applied Economic Sciences, 6(52), 1725-1731.

Sweeney, B. and McGarry, C. 2011. Commercial and Professional Audit Goals: Inculcation of Audit Seniors. International Journal of Auditing, 15(3), 316-332.

Tandy, P.R. and Moores, T. 1992. What Accountants Look For in a Job. The National Public Accountant, 37(3), 28-33.

Uyar, A., Gungormus, A.H. and Kuzey, C. 2011. Factors Affecting Students' Career Choice in Accounting: The Case of a Turkish University. American Journal of Business Education, 4(10), 29-38.

Vella, M. 2015. Why take on Accountancy as a Profession? Investigating Students' Motivations. Master in Accountancy Dissertation, Faculty of Economics, Management and Accountancy, University of Malta.

Yan, H. and Xie, S. 2016. How does auditors' work stress affect audit quality? Empirical evidence from the Chinese stock market. China Journal of Accounting Research, 9(4), 305-319.

Yunker, P. 2002. How to jump start your career. New Accountant, 18-21.

\section{Legislation:}

Accountancy Profession Act 1979, CAP. 281 of the Laws of Malta.

Accountancy Profession (Code of Ethics for Warrant Holders) Directive (No. 2) 2016 issued in terms of the Accountancy Profession Act (Cap 281) and of the Accountancy Profession Regulations 1986 (as amended).

Companies Act 1995, CAP. 386 of the Laws of Malta. 